\title{
T Cell Epitopes of the Timothy Grass Pollen Allergen Phl p 5 of Mice and Men and the Detection of Allergen-Specific T Cells Using Class II Ultimers
}

\author{
Angelika Stoecklinger ${ }^{\mathrm{a}}$ Sandra Scheiblhofer ${ }^{\mathrm{a}}$ Elisabeth Roesler ${ }^{\mathrm{a}}$ \\ Andreas Lang $^{\mathrm{a}}$ Gerd Fastner $^{\mathrm{b}}$ Felix Sedlmayer $^{\mathrm{b}}$ Roland Lang ${ }^{\mathrm{c}}$ \\ Martin Danzer $^{\mathrm{d}}$ Josef Thalhamer ${ }^{\mathrm{a}}$ Richard Weiss $^{\mathrm{a}}$ \\ ${ }^{a}$ Christian Doppler Laboratory for Allergy Diagnosis and Therapy, Department of Molecular Biology, \\ University of Salzburg, b University Clinic of Radiotherapy and Radiation Oncology and radART, and \\ 'Department of Dermatology, Paracelsus Medical University, Salzburg, and ${ }^{\mathrm{d}}$ Red Cross Transfusion \\ Service of Upper Austria, Linz, Austria
}

\section{Key Words}

Phl p $5 \cdot$ Epitope mapping $\cdot$ Tetramers $\cdot$ BALB/c mouse $\cdot$

C57BL/6 mouse

\begin{abstract}
Background: Knowledge of allergen-specific T cell epitopes is a prerequisite not only for therapeutic approaches but also for elucidating immunological mechanisms of type I allergy. Ex vivo detection of allergen-specific T cells using class II tetramer technology has become an important tool for investigating immune responses in atopic and healthy individuals. Methods: Using ${ }^{3} \mathrm{H}$-thymidine incorporation assays, $\mathrm{T}$ cell epitopes specific for the major timothy grass pollen allergen $\mathrm{Phl}$ p 5.0101 were mapped in 11 allergic donors and two different mouse strains. Different protocols for expansion/restimulation of T cells from the blood of allergic donors and detection of allergen-specific T cells by Class II Ultimer staining were evaluated. Results: We identified several new Phl p 5.0101 class II T cell epitopes in allergic patients and confirmed previously published ones. Additionally, we discovered the major T cell epitopes in BALB/C and C57BL/6 mice. Using a novel Class II Ultimer, we detected epitope-specific $T$ cells expanded from the blood of an allergic donor. Conclusions: Epitope mapping of Phl p 5.0101 revealed an im-
\end{abstract}

munodominant epitope in BALB/C and C57BL/6 mice and an immunodominant region in humans (amino acids 259-282), which was recognized by 8 out of 11 allergic donors. Detection of Phl p 5-specific T cells was demonstrated using a Class II Ultimer specific for epitope 196-210. Successful detection of ultimer-positive T cells was strongly dependent on a resting phase after in vitro expansion.

Copyright $\odot 2012$ S. Karger AG, Basel

\section{Introduction}

Due to a dramatic increase in prevalence during the past 2 decades, nowadays $25-40 \%$ of the population in industrialized countries are affected by type I allergic diseases.

Type I allergies are characterized by inappropriate immune responses to common environmental antigens derived from various sources, including tree and grass pollen, animal dander and the house dust mite [1]. The central role of allergen-specific CD4+ Th2 cells in the development and pathogenesis of allergic diseases is widely accepted $[2,3]$. In animal models, depletion of CD4+ T cells prevents the development of experimental asthma [4]. Similarly, in humans, the presence of CD4+

\section{KARGER}

Fax +4161306 1234

E-Mail karger@karger.ch

www.karger.com
(C) 2012 S. Karger AG, Basel

$1018-2438 / 12 / 1584-0326 \$ 38.00 / 0$

Accessible online at:

www.karger.com/iaa
Correspondence to: Dr. Josef Thalhamer

Christian Doppler Laboratory for Allergy Diagnosis and Therapy

Department of Molecular Biology, University of Salzburg

Hellbrunnerstrasse 34, AT-5020 Salzburg (Austria)

Tel. +43 6628044 5737, E-Mail Josef.Thalhamer@sbg.ac.at 
Th2 cells correlates with disease severity of asthma [5, 6]. IL-4 acts as the key cytokine, triggering differentiation of naïve $\mathrm{T}$ cells into Th2 cells, which induce the class switch to allergen-specific immunoglobulin $\mathrm{E}$ (IgE) production and allergic inflammation due to recruitment and activation of proinflammatory cells such as mast cells and eosinophils [7]. Although exposed to the same molecules, nonallergic individuals in contrast react with immune tolerance or deletion of allergen-reactive $\mathrm{T}$ cells, or with development of protective allergen-specific immune responses. The latter has been associated with naturally occurring regulatory $\mathrm{T}$ cells or inducible $\operatorname{Trl}$ cells, which function predominantly through secretion of IL-10 and/or TGF- $\beta$, thereby regulating allergic diseases in healthy individuals as well as in patients undergoing specific immunotherapy [8-12]. Another T helper cell type, which has been attributed to confer protection from allergy, is IFN- $\gamma$-secreting Th1 cells. Whereas allergen-specific CD4+ T cells from allergic patients are predominantly associated with a Th2 phenotype $[11,13,14]$, Th1 or mixed Th1/Treg cells can mainly be obtained from nonatopic individuals $[11,12$, 14-16]. Furthermore, it has been shown that specific immunotherapy can shift the allergic Th2 towards a nonallergic Th1 response [17-19].

For a better understanding of the cellular mechanisms associated with tolerance in healthy individuals and immunopathology in atopic patients, characterization of immunodominant epitopes of major allergens is critical. There is increasing evidence that $\mathrm{T}$ cell recognition of major allergens may often be attributed to discrete regions of overlapping epitopes with promiscuous human leukocyte antigen (HLA) binding capacity [2022]. Identification of such regions is of practical importance for therapeutic applications such as peptide-based immunotherapy $[23,24]$ or the use of hypoallergenic allergen derivatives, where conservation of immunodominant $\mathrm{T}$ cell epitopes has to be warranted $[25,26]$. Usage of peptides for restimulation during in vitro assays also facilitates the detection of low frequency allergen-specific CD4+ T cells, as, in contrast to restimulation with recombinant protein, no uptake and processing by antigen-presenting cells is required. Additionally, knowledge of $\mathrm{T}$ cell epitopes is a prerequisite for the detection and characterization of allergen-specific CD4+ T cell responses using major histocompatibility complex (MHC) class II peptide tetramer technology. In contrast to other methods developed to follow allergen-responding cells, such as the use of activation markers, fluorescent labeling or cytokine production, the tetramer technology is

Phl p 5 T Cell Epitopes of Mice and Men the only method to discriminate between allergen-specific cells and activated nonspecific cells $[13,14,24,27-$ 29]. While classical tetramers use fluorochrome-labeled streptavidin binding four biotinylated MHC molecules, class I pentamers, which consist of five MHC molecules, and Class II Ultimers displaying six MHCs have become commercially available (Proimmune, Oxford, UK). Due to their planar design and their increased number of binding sites, they show higher avidity to $\mathrm{T}$ cell receptors and therefore allow for a more sensitive detection of specific T cells.

Among inhalant allergens, hypersensitivity against components of grass pollen is rather frequent. Members of the group V grass pollen allergen family are about 30 $\mathrm{kDa}$ in size, derived exclusively from Pooideae grass species, and have been assigned high clinical relevance as they elicit IgE responses in $65-85 \%$ of grass pollen-allergic patients [30, 31]. Furthermore, these molecules are of particular importance because they display an extremely elevated IgE-binding capacity compared to members of other grass pollen groups [32]. We have previously studied prophylactic RNA vaccines encoding Phl p 5.0101 in mouse models [33] and are currently planning to transfer these results to the clinic in healthy human volunteers. Therefore, the knowledge of dominant Phl p 5.0101-specific $\mathrm{T}$ cell epitopes was of high interest to us to help generate sensitive methods for monitoring vaccine-induced immune responses in humans, including the use of ultimers, and also to optimize our readouts in the mouse model. While no Phl p 5.0101 T cell epitopes have been mapped in mice so far, in humans several epitopes have been described previously in a small study by Müller et al. [34] and a larger study by Oseroff et al. [35]. However, of the 12 (Müller et al.) and 33 (Oseroff et al.) timothy grass pollen-allergic patients, only a relatively small fraction actually recognized $\mathrm{Phl} p \mathrm{p} 5.0101$ peptides. Therefore, we considered it feasible to revalidate the previously published epitopes before testing Class II Ultimers for the detection of allergen-specific $\mathrm{T}$ cells. Consequently, we exclusively enrolled patients with high Phl p 5.0101-specific IgE titers to allow for higher response rates compared to the previous studies.

\section{Materials and Methods}

Protein and Peptides

A set of 92 peptides of 15 amino acids in length, overlapping by 3 residues, was generated to cover the sequence of Phl p 5.0101 (EMBL nucleotide sequence database accession No. X74735) and 
purchased as crude material from GenXpress (Wiener Neudorf, Austria) with nonamidated C-termini. Recombinant Phl p 5.0101 was purchased from Biomay AG (Vienna, Austria).

\section{Mapping of Epitopes in Two Mouse Strains}

C57BL/6 and BALB/c females aged 6-8 weeks were purchased from Charles River (Sulzfeld, Germany) and kept at the animal facility at the University of Salzburg. Animal experiments were conducted according to local guidelines approved by the Austrian Ministry of Science (Permit No. GZ 66.012/0004-II/10b/2010). Mice were immunized twice at a 2-week interval with $10 \mu \mathrm{g}$ recombinant Phl p 5 in PBS adjuvanted with $\mathrm{Al}(\mathrm{OH})_{3}$ by intradermal injection at the abdomen. Two weeks after the second immunization, the animals were sacrificed and lymphocytes were prepared as described elsewhere [36]. Triplicate cultures of the lymphocytes $\left(2 \times 10^{5} /\right.$ well $)$ were incubated in 96 -well round-bottom plates (Greiner, Kremsmünster, Austria) with either 1 of the 92 peptides $(2.5 \mu \mathrm{g} / \mathrm{ml})$, recombinant $\mathrm{Phl} \mathrm{p} 5$ protein $(10 \mu \mathrm{g} / \mathrm{ml})$ or medium alone (MEM; PAA Laboratories, Pasching, Austria, supplemented as described by Hartl et al.; [36]) for $48 \mathrm{~h}$ at $37^{\circ} \mathrm{C}$. ${ }^{3} \mathrm{H}$-thymidine $(0.5 \mu \mathrm{Ci} /$ well $)$ was added for another $16 \mathrm{~h}$ before harvesting the cells using a Harvester 96 Mach IIIM (Tomtec Inc., Hamden, Conn., USA) and measurement of the incorporated radioactivity in a scintillation counter (Wallac Trilux 1450 Microbeta, PerkinElmer, Finland). Stimulation indices were calculated by determining the ratio between $\mathrm{cpm}$ obtained in the cultures with peptide and cpm obtained in the same cultures without peptide.

\section{Subjects}

Peripheral blood was obtained with consent from grass pollenallergic patients, who had been recruited at the University Clinic of Dermatology, Paracelsus Medical University, Salzburg, according to a positive ImmunoCap (Phadia, Uppsala, Sweden) for Phl p 5-specific IgE (RAST class $>2$ ). Blood samples from a healthy donor with no history of atopy were obtained from one of the authors of this paper. HLA-DRB1 typing was performed at the Red Cross Transfusion Service of Upper Austria, Linz, as previously described [37]. All clinical investigations were conducted according to the principles expressed in the Declaration of Helsinki and all data were analyzed anonymously.

Peripheral Blood Mononuclear Cell Isolation and in vitro Expansion of Phl p 5-Specific T Cells

Peripheral blood mononuclear cells (PBMCs) were isolated from freshly drawn heparinized peripheral blood by Ficoll-Paque $^{\mathrm{TM}}$ PLUS density gradient centrifugation (GE Healthcare, Austria), washed three times with Dulbecco's PBS (PAA Laboratories) and resuspended in X-VIVO ${ }^{\mathrm{TM}} 15$ medium (Lonza, Basel, Switzerland) supplemented with $2 \mathrm{mM} \mathrm{L}$-glutamine, $100 \mathrm{U} / \mathrm{ml}$ penicillin and $0.1 \mathrm{mg} / \mathrm{ml}$ streptomycin. Isolated PBMCs $\left(2 \times 10^{6} / \mathrm{ml}\right)$ were stimulated in 24-well plates with recombinant $\mathrm{Phl} \mathrm{p} 5(10 \mu \mathrm{g} / \mathrm{ml})$ in a total volume of $1 \mathrm{ml}$ complete X-VIVO ${ }^{\mathrm{TM}} 15$. After 5 days at $37^{\circ} \mathrm{C}, 10 \mathrm{U} / \mathrm{ml} \mathrm{IL}-2$ was added. Following another 5 days of incubation, cells were washed in X-VIVO ${ }^{\mathrm{TM}} 15$ supplemented with $1 \%$ human serum once for the removal of recombinant protein and IL-2 and incubated for a resting phase of 11 days. Some of the T cells used for MHC Class II Ultimer staining were subsequently restimulated with recombinant protein in the presence of irradiated (60 Gy) autologous PBMCs and IL-2 for another 5 or 7 days.
Alternatively, a faster protocol for the expansion of T cells previously published by Macaubas et al. [13] was employed, which omits the resting phase. In this case, T cells were cultured for 6 days with recombinant $\mathrm{Phl} p 5$, then harvested, incubated for another 3 days with antigen together with irradiated autologous PBMCs and IL-2, harvested again and directly used for MHC Class II Ultimer staining.

\section{Mapping of Epitopes by T Cell Proliferation Assay}

Expanded T cells were harvested, washed once in X-VIVO ${ }^{\mathrm{TM}}$ 15 and incubated in 96-well round-bottom plates $\left(2 \times 10^{4} /\right.$ well $)$ in duplicate cultures (final volume $150 \mu \mathrm{l}$ ) in the presence of irradiated autologous PBMCs $\left(5 \times 10^{4} /\right.$ well $)$ as antigen-presenting cells with either 1 of the 92 peptides $(3 \mu \mathrm{g} / \mathrm{ml})$, recombinant Phl p $5(10 \mu \mathrm{g} / \mathrm{ml})$ or concanavalin A $(0.25 \mu \mathrm{g} / \mathrm{ml})$, or medium (XVIVO $^{\mathrm{TM}} 15$ with $1 \%$ human serum) alone. For control, some wells received no $\mathrm{T}$ cells but only irradiated autologous PBMCs and concanavalin A. After a 48-hour incubation time, ${ }^{3} \mathrm{H}$-thymidine $(0.5 \mu \mathrm{Ci} /$ well $)$ was added to the wells for $16 \mathrm{~h}$. Then the cells were harvested and the incorporated radioactivity was measured. Stimulation indices were calculated by determining the ratio between cpm obtained in cultures with $\mathrm{T}$ cells plus irradiated autologous PBMCs and peptide, and cpm obtained in the same cultures without peptide. Responses were considered positive at a stimulation index greater than 2 .

\section{Staining with MHC Class II Peptide Ultimer}

An HLA-DRB1*01:01 ultimer was synthesized, complexed with Phl p 5 $232-246$ (yesykfipaleaavk), and conjugated to PE by Proimmune. Expanded T cells were distributed in 96-well v-bottom plates $\left(2-5 \times 10^{5} /\right.$ well $)$, washed once with PBS $+0.1 \%$ BSA, and stained with $10 \mu \mathrm{l}$ of the ultimer in PBS $+0.1 \%$ BSA for $2 \mathrm{~h}$ at $37^{\circ} \mathrm{C}$. After washing the cells twice in cold PBS + 0.1\% BSA, APC-Cy7labeled anti-CD4 antibody (BD PharMingen, San Jose, Calif., USA) was added for 20 min on ice in the dark. Subsequently, the cells were washed three times. Five minutes before analysis on a FACSCanto II flow cytometer, $4 \mu \mathrm{l}$ 7AAD viability staining solution (eBioscience, San Diego, Calif., USA) was added to stain the dead cells.

\section{Results}

\section{Identification of Phl p 5 T Cell Epitopes in Mice and Men}

PBMCs from $11 \mathrm{Phl}$ p 5.0101 allergic donors were expanded in vitro using the recombinant allergen. The resulting Phl p 5.0101-specific T cells were subsequently restimulated with an array of 15 -mer peptides spanning the entire sequence of the protein with a 3 amino acid overlap. Proliferation was measured by ${ }^{3} \mathrm{H}$-thymidine uptake. Figure 1 shows a comprehensive summary of all the epitopes identified in the current study and compares the results to published epitopes $[34,35]$. As summarized in figure 2, epitopes in the $\mathrm{N}$-terminal part of $\mathrm{Phl}$ p 5.0101 are only recognized by a minor fraction of the patients. 


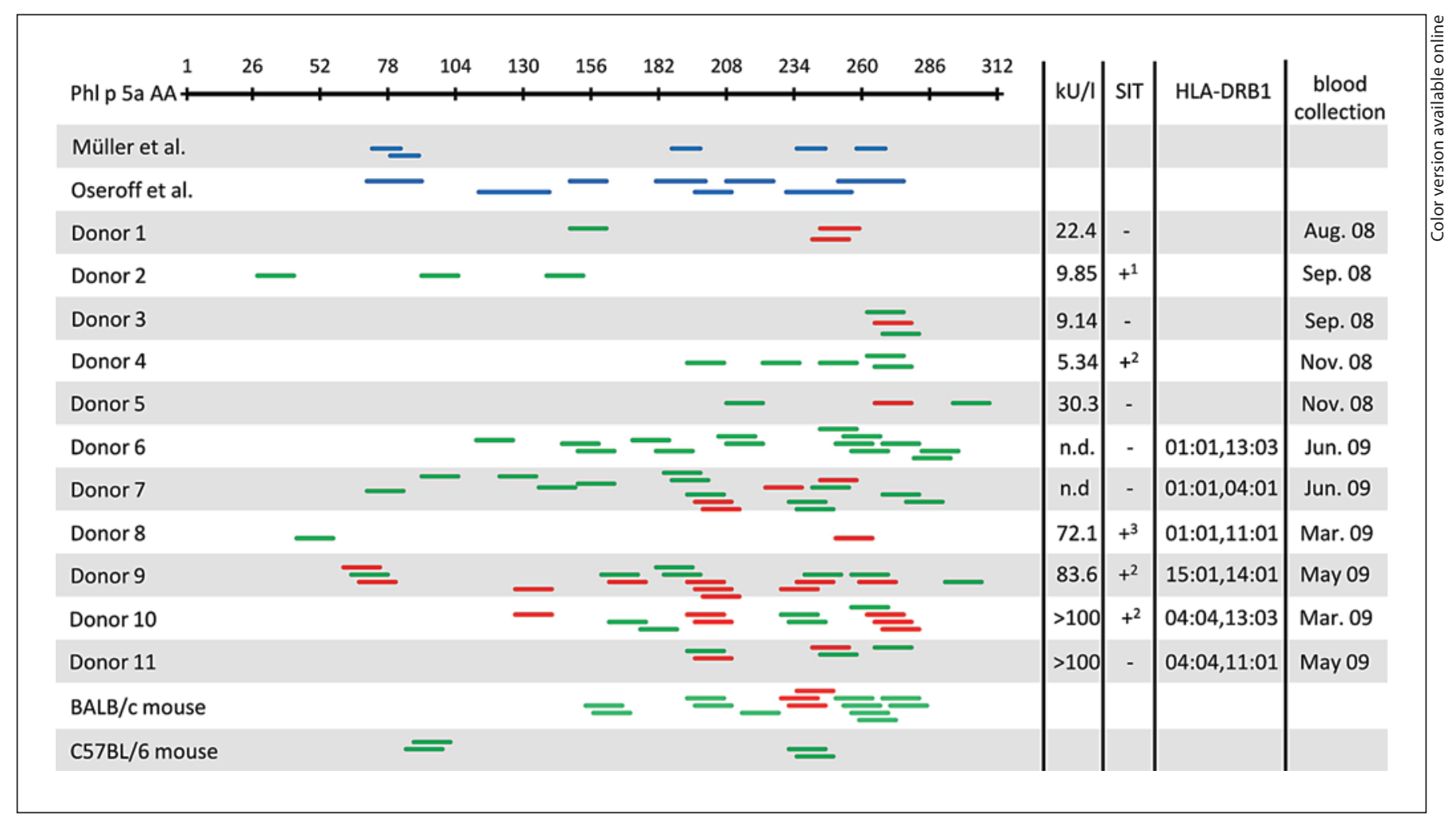

Fig. 1. Phl p 5.0101 T cell epitopes of mice and men. Previously published epitopes/immunodominant regions from the studies by Müller et al. [34] and Oseroff et al. [35] are shown in blue (colors refer to the online version only). Epitopes mapped in 11 allergic donors as well as in $\mathrm{BALB} / \mathrm{c}$ and $\mathrm{C} 57 \mathrm{BL} / 6$ mice are shown in green (stimulation index $>2$ ) or red (stimulation index $>3$ ). Epitopes are displayed corresponding to their location within $\mathrm{Phl} p$ 5.0101 (accession No. X74735; shown by the black line at the top). $\mathrm{Phl}$ p 5-specific IgE levels of the respective donors are shown as kilounits/liter $(\mathrm{kU} / \mathrm{l})$ where available (n.d. = not done). HLADRB1 alleles were determined for selected donors. + or - indicates whether the donor has undergone SIT before epitope mapping: ${ }^{1}$ SIT against grass pollen for 1 year between 2000 and 2002 (may have taken Grazax ${ }^{\circledR}$ during a placebo-controlled study a few days before blood sampling); ${ }^{2}$ SIT against Alutard SQ grass pollen shortly before blood sampling; ${ }^{3}$ SIT against grass and tree pollen between 1996 and 1999.
Fig. 2. Epitope distribution among timothy grass pollen-allergic patients [34, 35] and $\mathrm{Phl}$ p 5.0101-allergic patients. Antigenic regions (displayed in dark grey) are shown in relation to their amino acid position within the sequence of Phl p 5.0101. The number of patients recognizing an epitope in a given region is displayed as a fraction of the total number of donors in a given study. The top panel shows the summarized results from the study by Müller et al. [34], the middle panel (shaded in grey) of Oseroff et al. [35], and the bottom panel of the current study.

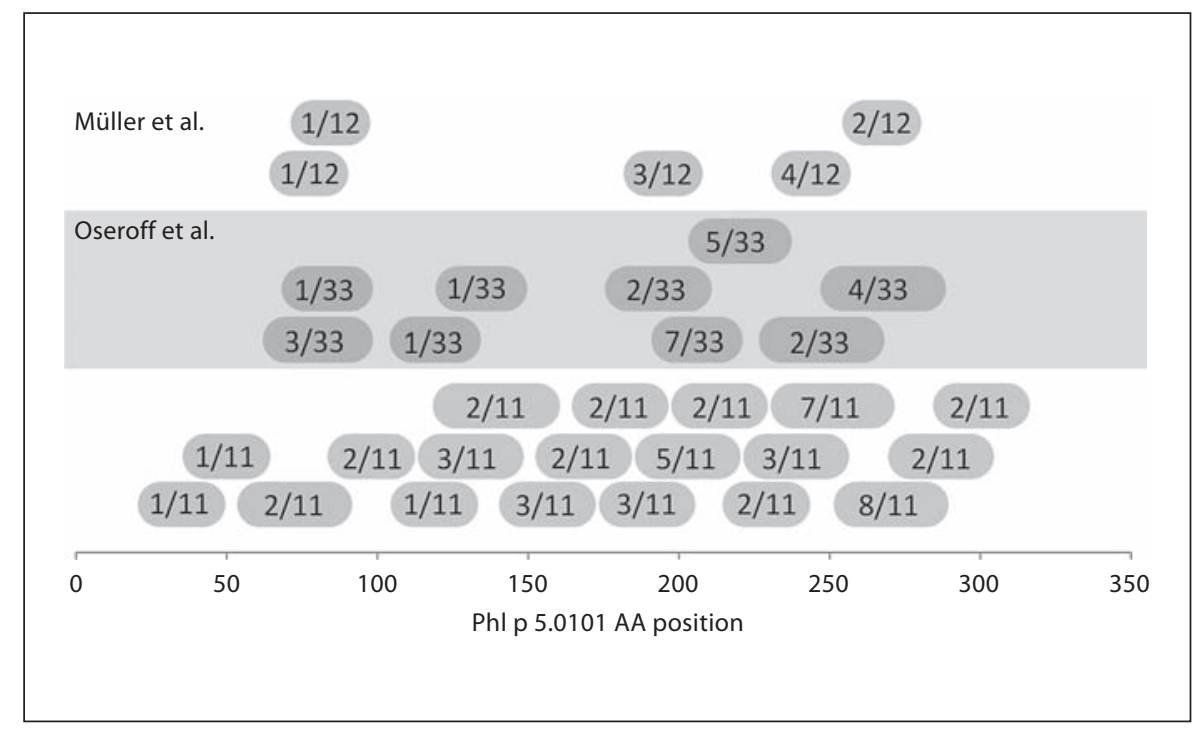

Int Arch Allergy Immunol 2012;158:326-334 
Fig. 3. Detection of allergen-specific $\mathrm{T}$ cells using Class II Ultimer. T cells expanded in vitro were analyzed by flow cytometry after a resting phase of 11 days (a), followed by 5 (b) or 7 (c) days of restimulation with recombinant allergen. Viable $\mathrm{T}$ helper cells (7AAD-, CD4+) were gated and Phl p 5 $5_{232-245}$-specific TCR surface expression was detected by staining with DRB1 $^{*} 01: 01 /$ Phl p 5 52-246 ultimer.
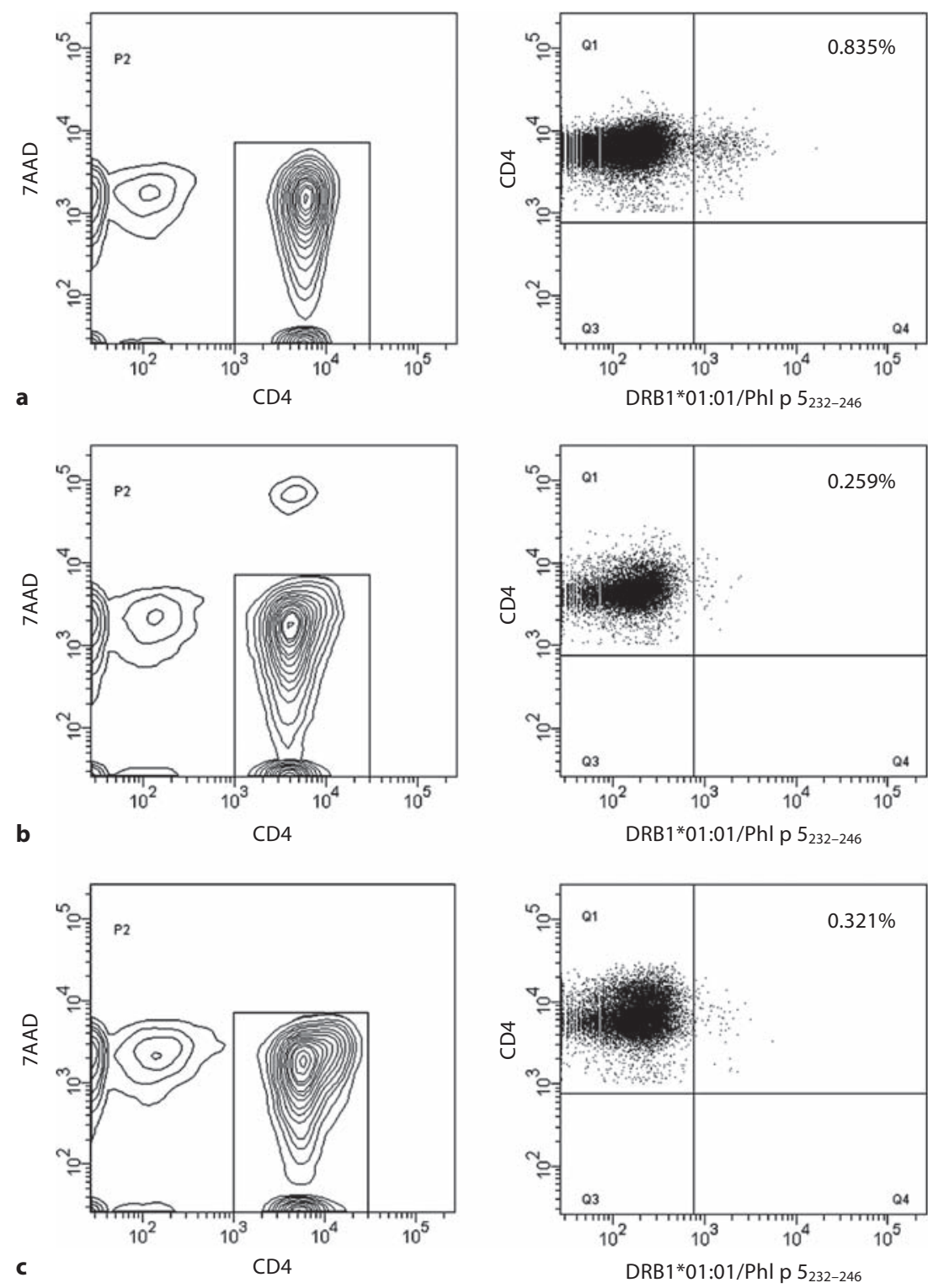

In contrast, we found that $73 \%(8 / 11)$ of patients allergic to $\mathrm{Phl}$ p 5.0101 recognized epitopes in the region ranging from amino acids 259 to 282.

Restimulation of splenocytes from sensitized BALB/c mice, using a pool of the peptides found in this study, allowed for more sensitive detection of allergen-specific $\mathrm{T}$ cells compared to restimulation with recombinant protein (online suppl. fig. 1; for all online suppl. material, see www.karger.com/doi/10.1159/000333551).
Detection of Phl p 5.0101-Specific T Cells in Allergic Donors using Class II Ultimers

As a next step we investigated whether the mapped epitopes could be used for the detection of specific T cells in allergic donors with Class II Ultimer technology (Proimmune). An initially selected epitope 196-210 (afkvaataanaapan), which was recognized by 5 out of 11 donors, and 7 out of 33 in a recent study [35], did not result in a functional product as a DRB1*01:01 ultimer by the synthesis procedure. Alternatively, we selected epitope 232- 
Fig. 4. T cells expanded in vitro were directly analyzed by flow cytometry without a preceding resting phase. The plots show an allergic donor reactive against peptide 232-246 (a), an allergic donor nonresponsive for the respective peptide (b) and a nonallergic donor (c). Viable T helper cells (7AAD-, CD4+) were gated and Phl p 5232-245-specific TCR surface expression was detected by staining with $\mathrm{DRB}^{*} 01$ : 01/Phl p 5232-246 ultimer.
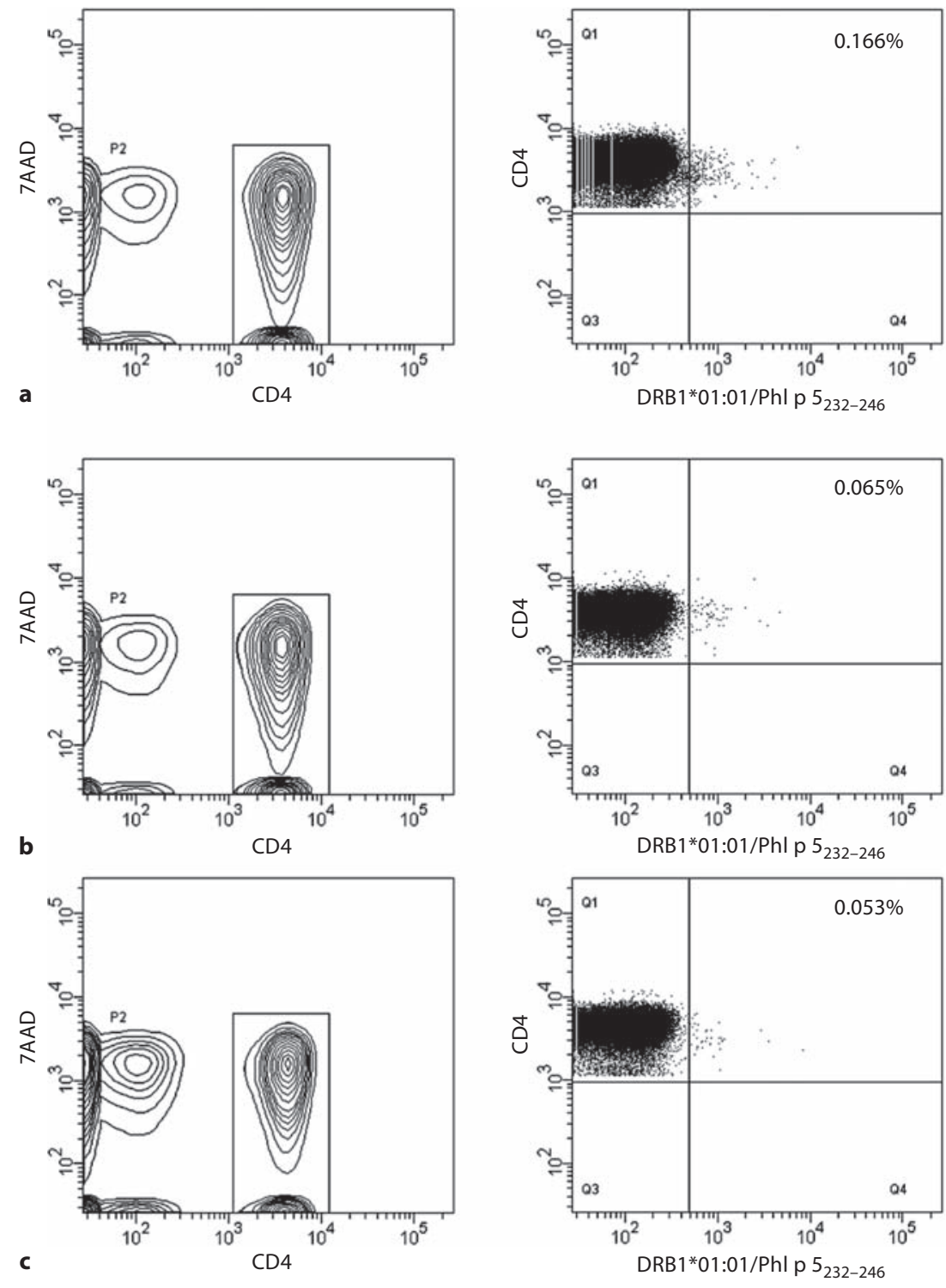

246 (yesykfipaleaavk), which was recognized by 2 out of 11 donors. We chose this epitope for a proof of principle, since a respective donor with a suitable HLA type (donor 7, DRB1*01:01) allowing for ultimer synthesis, was available at the institute for repeated blood sampling. Using this epitope finally resulted in a functional ultimer.

PBMCs from donor 7 were expanded in vitro with recombinant Phl p 5.0101 and subsequently rested for 11 days in the absence of antigen as described in Materials and Methods. As shown in figure 3a, $0.835 \%$ of expanded

$\mathrm{T}$ cells were positive for $\mathrm{DRB1}{ }^{*} 01: 01 / \mathrm{P}_{232-246}$ ultimer. Subsequent restimulation with antigen for 5 (fig. 3b) or 7 days (fig. 3c) dramatically reduced the number of T cells that were detectable by ultimer staining.

\section{Staining of T Cells Expanded in vitro without a \\ Resting Phase Results in Low Detection Rate}

To evaluate a faster protocol that has been developed for tetramer staining and simultaneous intracellular cytokine detection [13], we compared T cells from donor 7 
(fig. 4a; an allergic donor specifically recognizing epitope 232-246), donor 6 (fig. 4b; an allergic donor of the same HLA-type but not recognizing epitope 232-246) and a nonallergic donor (fig. 4c). Enhanced numbers of specific T cells $(0.166 \%)$ could be detected solely in donor 7, who specifically recognizes epitope 232-246 (fig. 3a), whereas in the allergic donor 6 (fig. $4 \mathrm{~b}$ ) the amount of specific $\mathrm{T}$ cells was similar as in a nonallergic donor (fig. 4c). The presented data clearly demonstrate that ultimer/tetramer staining of cells after a resting period (compare fig. 3a to fig. 4b) is highly superior to the staining of freshly expanded cells and the usefulness of short protocols seems to be restricted to the detection of $\mathrm{T}$ cell clones of high abundance.

\section{Discussion}

Identification of immunodominant $\mathrm{T}$ cell epitopes in allergic individuals is an important prerequisite for novel immunotherapies and improved diagnostics. In our current study we investigated Phl p 5-specific T cell epitopes of mice and Phl p 5-allergic individuals. We could confirm all previously published epitopes and also identify several new ones. Additionally, we mapped $\mathrm{Phl} p$ 5.0101-specific $\mathrm{T}$ cell epitopes recognized by BALB/c and C57BL/6 mice and, for the first time, identified a clearly immunodominant epitope (region 232-252) that is recognized by both mouse strains as well as by $27 \%(3 / 11)$ of human donors. $\mathrm{T}$ cell epitopes in allergic patients were highly clustered in the $\mathrm{C}$-terminal region of the molecule with 73\% (8/11) recognizing epitopes in the region ranging from amino acids 259 to 282 , underscoring a largely HLA-independent immunodominance of this part of the molecule. Using a bioinformatic prediction algorithm for HLA promiscuity, it has recently been demonstrated that immunodominant regions of an allergen rather represent hot spots presented by multiple HLA molecules than epitopes specifically restricted by certain HLAs, thus reflecting a processing propensity to preferentially generate certain protein fragments [35]. Five of the 11 donors in our study have previously received specific immunotherapy (SIT) against grass pollen and 3 of them react to a reduced number of epitopes compared to the other subjects. This is in line with the study of Oseroff et al. [35], who found that 'SIT donors manifested weaker and less consistent epitope-specific T cell responses when compared with non-SIT allergic individuals; however, these responses appear similar in terms of epitope specificity and the pattern of cytokines observed to those in allergic donors.' SIT seems to be rather associated with an overall downregulation of the response against the allergen and not a shift in epitope specificity or immune polarization [35]. Two out of 8 donors recognizing $\mathrm{Phl} p$ 5.0101-specific peptides in the Müller et al. [34] study had previously undergone SIT; however, since only 1 or 2 epitopes per donor were detected no conclusions could be drawn as to whether SIT had an effect on the T cell repertoire in that study.

Detection of allergen-specific T cells directly ex vivo using tetramer technology is only possible for most abundant $\mathrm{T}$ cell clones. In vitro expansion of $\mathrm{T}$ cells by antigen restimulation is therefore almost always required. It has been speculated that long-term in vitro restimulation for the enrichment of allergen-specific $\mathrm{T}$ cells could potentially lead to selective expansion of certain T cell subsets. However, it could be demonstrated in the case of T cells specific for the major birch pollen allergen Bet $\mathrm{v}$ 1a that there is no difference in phenotype or cytokine secretion profile between short- and long-term in vitro expanded $\mathrm{T}$ cells [14]. Even during peak birch pollen exposure and by using a class II tetramer against the immunodominant epitope of Bet v 1a, tetramer-positive CD4+ T cells could be detected directly ex vivo with a frequency of $0.3-0.5 \%$ of circulating CD $4+\mathrm{T}$ cells in only 1 out of 20 birch pollen-allergic patients and 1 out of 9 healthy subjects [14]. Alternatively, detection of tetramer-positive $\mathrm{T}$ cells has been achieved by direct enrichment using magnetic beads [29].

Our data indicate that a resting phase after expansion may be critical as subsequent restimulation with antigen dramatically reduced the numbers of $\mathrm{T}$ cells that were detectable by ultimer staining (fig. 3). This is in accordance with data showing that after ligation of the $\mathrm{T}$ cell receptors (TCR) by MHC-peptide complexes, TCR surface expression is downregulated by intracellular retention of internalized complexes [38], thus interfering with tetramer staining. This problem gains special relevance when restimulation of $\mathrm{T}$ cells is required for the staining of cytokines, but it can be solved by using a cytokine secretion assay and employing only a short antigen restimulation phase after tetramer staining. Alternatively, cytokine profiles can be established by sorting tetramer-positive cells followed by qPCR analysis [14]. Also, careful titration of the antigen used for restimulation can at least partly address this problem [39].

Fast protocols for tetramer staining and simultaneous intracellular cytokine detection have been described where $\mathrm{T}$ cells are expanded for 6 days and are subsequently restimulated for 3 days without a resting phase [13]. 
However, we detected a much lower number of allergenspecific T cells using freshly expanded cells (fig. 4b) compared to rested cells (fig. 3a), indicating that such protocols are always a compromise between tetramer detection (requiring rested cells) and cytokine detection (requiring antigen restimulation). No allergen-specific T cells could be detected in a nonallergic donor, which is in agreement with the results of Macaubas et al. [13] and Van Overtvelt et al. [14], who consistently found fewer specific $\mathrm{T}$ cells in healthy than in allergic donors. Moreover, T cells of the former required longer in vitro restimulation to achieve significant responses.

In summary, we confirmed previously mapped epitopes of T helper cells recognizing Phl p 5.0101 and iden- tified several new epitopes in allergic patients. Furthermore, we identified the immunodominant Phl p 5.0101 T cell epitope in BALB/c and C57BL/6 mice. For the first time, we demonstrated detection of Phl p 5232-246-specific $\mathrm{T}$ cells using Class II Ultimers. Comparing two different protocols for $\mathrm{T}$ cell expansion, we documented the importance of antigen restimulation concerning the detection of specific T cells.

\section{Acknowledgments}

This work was supported by Biomay AG and the Christian Doppler Research Association (both Vienna, Austria).

\section{References}

$>1$ Peden D, Reed CE: Environmental and occupational allergies. J Allergy Clin Immunol 2010;125:S150-S160.

72 Kay AB: Allergy and allergic diseases: second of two parts. N Engl J Med 2001;344: 109-113.

$\checkmark 3$ Kay AB: Allergy and allergic diseases: first of two parts. N Engl J Med 2001;344:30-37.

4 Gavett SH, Chen X, Finkelman F, Wills-Karp M: Depletion of murine CD4+ T lymphocytes prevents antigen-induced airway hyperreactivity and pulmonary eosinophilia. Am J Respir Cell Mol Biol 1994; 10:587-593.

$>5$ Robinson DS, Hamid Q, Ying S, Tsicopoulos A, Barkans J, Bentley AM, Corrigan C, Durham SR, Kay AB: Predominant $\mathrm{T}_{\mathrm{H} 2}$-like bronchoalveolar T-lymphocyte population in atopic asthma. N Engl J Med 1992;326: 298-304.

$\checkmark 6$ Robinson DS, Ying S, Bentley AM, Meng Q, North J, Durham SR, Kay AB, Hamid Q: Relationships among numbers of bronchoalveolar lavage cells expressing messenger ribonucleic acid for cytokines, asthma symptoms, and airway methacholine responsiveness in atopic asthma. J Allergy Clin Immunol 1993;92:397-403.

-7 Larche M, Akdis CA, Valenta R: Immunological mechanisms of allergen-specific immunotherapy. Nat Rev Immunol 2006;6: 761-771.

$>8$ Ling EM, Smith T, Nguyen XD, Pridgeon C, Dallman M, Arbery J, Carr VA, Robinson DS: Relation of CD4+CD25+ regulatory Tcell suppression of allergen-driven $\mathrm{T}$-cell activation to atopic status and expression of allergic disease. Lancet 2004;363:608-615.

$>9$ Shi HZ, Qin XJ: CD4+CD25+ regulatory T lymphocytes in allergy and asthma. Allergy 2005;60:986-995.

10 Francis JN, Till SJ, Durham SR: Induction of IL-10+CD $4+\mathrm{CD} 25+\mathrm{T}$ cells by grass pollen immunotherapy. J Allergy Clin Immunol 2003;111:1255-1261.

11 Akdis M, Verhagen J, Taylor A, Karamloo F, Karagiannidis C, Crameri R, Thunberg S, Deniz G, Valenta R, Fiebig H, Kegel C, Disch $\mathrm{R}$, Schmidt-Weber CB, Blaser K, Akdis CA: Immune responses in healthy and allergic individuals are characterized by a fine balance between allergen-specific $\mathrm{T}$ regulatory 1 and T helper 2 cells. J Exp Med 2004;199: 1567-1575.

12 Jutel M, Akdis M, Budak F, Aebischer-Casaulta C, Wrzyszcz M, Blaser K, Akdis CA: IL10 and TGF- $\beta$ cooperate in the regulatory $\mathrm{T}$ cell response to mucosal allergens in normal immunity and specific immunotherapy. Eur J Immunol 2003;33:1205-1214.

13 Macaubas C, Wahlstrom J, Galvao da Silva AP, Forsthuber TG, Sonderstrup G, Kwok WW, DeKruyff RH, Umetsu DT: Allergenspecific MHC class II tetramer+ cells are detectable in allergic, but not in nonallergic, individuals. J Immunol 2006;176:5069-5077.

14 Van Overtvelt L, Wambre E, Maillere B, von Hofe E, Louise A, Balazuc AM, Bohle B, Ebo D, Leboulaire C, Garcia G, Moingeon P: Assessment of Bet v 1-specific CD4+ T cell responses in allergic and nonallergic individuals using MHC class II peptide tetramers. J Immunol 2008;180:4514-4522.

-15 Bullens DM, De Swerdt A, Dilissen E, Kasran A, Kroczek RA, Cadot P, Casaer P, Ceuppens JL: House dust mite-specific $\mathrm{T}$ cells in healthy non-atopic children. Clin Exp Allergy 2005;35:1535-1541.

16 Ebner C, Schenk S, Najafian N, Siemann U, Steiner R, Fischer GW, Hoffmann K, Szepfalusi Z, Scheiner O, Kraft D: Nonallergic individuals recognize the same $T$ cell epitopes of Bet $\mathrm{v} 1$, the major birch pollen allergen, as atopic patients. J Immunol 1995;154:19321940.
-17 Ebner C, Siemann U, Bohle B, Willheim M, Wiedermann U, Schenk S, Klotz F, Ebner H, Kraft D, Scheiner O: Immunological changes during specific immunotherapy of grass pollen allergy: reduced lymphoproliferative responses to allergen and shift from $\mathrm{TH} 2$ to TH1 in T cell clones specific for Phl p 1, a major grass pollen allergen. Clin Exp Allergy 1997;27:1007-1015.

18 Till S: Immunotherapy: readdressing the balance between TH2 and TH1 cells. Clin Exp Allergy 1997;27:981-985.

19 Jutel M, Pichler WJ, Skrbic D, Urwyler A, Dahinden C, Müller UR: Bee venom immunotherapy results in decrease of IL-4 and IL-5 and increase of IFN-gamma secretion in specific allergen-stimulated $\mathrm{T}$ cell cultures. J Immunol 1995;154:4187-4194.

20 Texier C, Pouvelle-Moratille S, Buhot C, Castelli FA, Pecquet C, Menez A, Leynadier F, Maillere B: Emerging principles for the design of promiscuous HLA-DR-restricted peptides: an example from the major bee venom allergen. Eur J Immunol 2002;32: 3699-3707.

21 de Lalla C, Sturniolo T, Abbruzzese L, Hammer J, Sidoli A, Sinigaglia F, PaninaBordignon P: Cutting edge: identification of novel T cell epitopes in Lol p5a by computational prediction. J Immunol 1999; 163: 1725-1729.

22 Friedl-Hajek R, Spangfort MD, Schou C, Breiteneder $\mathrm{H}$, Yssel $\mathrm{H}$, Joost van Neerven RJ: Identification of a highly promiscuous and an HLA allele-specific T cell epitope in the birch major allergen Bet $\mathrm{v}$ 1: HLA restriction, epitope mapping and TCR sequence comparisons. Clin Exp Allergy 1999; 29:478-487.

23 Ali FR, Larche M: Peptide-based immunotherapy: a novel strategy for allergic disease. Expert Rev Vaccines 2005;4:881-889. 
-24 Campbell JD, Buckland KF, McMillan SJ, Kearley J, Oldfield WL, Stern LJ, Gronlund $\mathrm{H}$, van Hage M, Reynolds CJ, Boyton RJ, Cobbold SP, Kay AB, Altmann DM, Lloyd $\mathrm{CM}$, Larche M: Peptide immunotherapy in allergic asthma generates IL-10-dependent immunological tolerance associated with linked epitope suppression. J Exp Med 2009; 206:1535-1547.

25 Campana R, Vrtala S, Maderegger B, Jertschin P, Stegfellner G, Swoboda I, FockeTejkl M, Blatt K, Gieras A, Zafred D, Neubauer A, Valent P, Keller W, Spitzauer S, Valenta R: Hypoallergenic derivatives of the major birch pollen allergen bet $\mathrm{v} 1$ obtained by rational sequence reassembly. J Allergy Clin Immunol 2010;126:1024-1031.

-26 Saarne T, Kaiser L, Gronlund H, Rasool O, Gafvelin G, van Hage-Hamsten M: Rational design of hypoallergens applied to the major cat allergen Fel d 1. Clin Exp Allergy 2005; 35:657-663.

27 Bateman EA, Ardern-Jones MR, Ogg GS: Persistent central memory phenotype of circulating Fel d 1 peptide/DRB1*0101 tetramer-binding CD4+ T cells. J Allergy Clin Immunol 2006;118:1350-1356.
Kinnunen T, Jutila K, Kwok WW, RytkonenNissinen M, Immonen A, Saarelainen S, Narvanen A, Taivainen A, Virtanen T: Potential of an altered peptide ligand of lipocalin allergen Bos d 2 for peptide immunotherapy. J Allergy Clin Immunol 2007;119: 965-972.

29 Kwok WW, Roti M, Delong JH, Tan V, Wambre E, James EA, Robinson D: Direct ex vivo analysis of allergen-specific CD4+ T cells. J Allergy Clin Immunol 2010;125:1407-1409.

30 Andersson K, Lidholm J: Characteristics and immunobiology of grass pollen allergens. Int Arch Allergy Immunol 2003;130:87-107.

31 Mohapatra SS, Lockey RF, Shirley S: Immunobiology of grass pollen allergens. Curr Allergy Asthma Rep 2005;5:381-387.

32 Vrtala S, Susani M, Sperr WR, Valent P, Laffer S, Dolecek C, Kraft D, Valenta R: Immunologic characterization of purified recombinant timothy grass pollen (Phleum pratense) allergens (Phl p 1, Phl p 2, Phl p 5). J Allergy Clin Immunol 1996;97:781-787.

33 Roesler E, Weiss R, Weinberger EE, Fruehwirth A, Stoecklinger A, Mostbock S, Ferreira F, Thalhamer J, Scheiblhofer S: Immunize and disappear-safety-optimized mRNA vaccination with a panel of 29 allergens. J Allergy Clin Immunol 2009;124:1070-1077.

34 Müller WD, Karamfilov T, Kahlert H, Stüwe HT, Fahlbusch B, Cromwell O, Fiebig H, Jäger L: Mapping of T cell epitopes of Phl p 5: evidence for crossreacting and non-crossreacting $\mathrm{T}$ cell epitopes within Phl p 5 isoallergens. Clin Exp Allergy 1998;28:1538-1548.
35 Oseroff C, Sidney J, Kotturi MF, Kolla R, Alam R, Broide DH, Wasserman SI, Weiskopf D, McKinney DM, Chung JL, Petersen A, Grey H, Peters B, Sette A: Molecular determinants of $\mathrm{T}$ cell epitope recognition to the common timothy grass allergen. J Immunol 2010;185:943-955.

36 Hartl A, Weiss R, Hochreiter R, Scheiblhofer $S$, Thalhamer J: DNA vaccines for allergy treatment. Methods 2004;32:328-339.

37 Danzer M, Polin H, Proll J, Hofer K, Fae I, Fischer GF, Gabriel C: High-throughput sequence-based typing strategy for HLA-drbl based on real-time polymerase chain reaction. Hum Immunol 2007;68:915-917.

38 Liu H, Rhodes M, Wiest DL, Vignali DA: On the dynamics of TCR:CD3 complex cell surface expression and downmodulation. Immunity 2000;13:665-675.

39 Dimopoulos N, Jackson HM, Ebert L, Guillaume P, Luescher IF, Ritter G, Chen W: Combining MHC tetramer and intracellular cytokine staining for $\mathrm{CD} 8+\mathrm{T}$ cells to reveal antigenic epitopes naturally presented on tumor cells. J Immunol Methods 2009;340:9094. 